\author{
V International Forum on Teacher Education
}

\title{
Sociocultural Risks of the Educational Environment as a Basis for the Classification of Schools by Level of Socio- Psychological Safety
}

\author{
Elvira N. Gilemkhanova*
}

Kazan Federal University, 420008, Kazan (Russia), 18 Kremlyovskaya street

\begin{abstract}
The educational environment and its socio-psychological safety is a significant social issue for schoolchildren (Bronfenbrenner, 1989). This issue continues to be a primary focus of studies on the sociopsychological safety of the educational environment (Reijntjes, Kamphuis, Prinzie, \& Telch, 2010) including possible sociocultural risks. The study focused on the following research question: How do sociocultural risks influence the socio-psychological safety of the educational environment? In order to respond to the question, we examined the types of different educational environments by the level of sociopsychological safety based on the assessment of the socio-cultural risks. The risks are based on the analysis of the following contextual factors: geographic, economic, social, educational, upbringing, and psychological. The study was conducted in nine regions of the Republic of Tatarstan (Russia) with varied indicators of the contextual factors. The study sample consisted of 3,232 pupils from 36 schools. Main results of the study indicate different types of the educational environments based on a configuration of contextual factors defining the level of socio-psychological safety using the principal component method. Significance. The study's findings suggest that close consideration of the configuration of contextual factors along with sociocultural risks could increase soci-psychological safety of the educational environment.
\end{abstract}

Keywords: socio-psychological safety; sociocultural risk; types of educational environment.

\section{(C) 2019 Elvira N. Gilemkhanova}

This is an open access article distributed under the terms of the Creative Commons Attribution License (CC BY 4.0), which permits unrestricted use, distribution, and reproduction in any medium, provided the original author and source are credited.

Published by Kazan federal university and peer-reviewed under responsibility of IFTE-2019 (V International Forum on Teacher Education)

\footnotetext{
* Corresponding author. Tel.: +78439195660; e-mail address: enkazan@mail.ru
} 


\section{Introduction}

The developmental tendencies of the society and civilization determine the inclusion of the educational environment in various levels of society. This determines the multi-level and multi-factorial nature of the educational environment, its integration into the socio-cultural system and its dependency on it.

As Argyris (1958) emphasizes studying human behavior in schools, as in any other organizations, involves order and conceptualization of simultaneously existing, multilevel, mutually interacting variables. As a result, an important methodological issue of research into the influence of various factors on the educational environment is touched upon. It is connected with the choice of level of a research and the variables corresponding to this level. A serious methodological difficulty consists in distinguishing between contextual and individual characteristics of the educational environment. McPartland and Epstein (1975) studied school environments and pointed at the limitations of studies of school environments for further research. At the same time, some scientists, for example, Brookover and Erickson (1975) note that ineffectiveness of previous empirical research of the educational environment is caused by unconstructive models, inadequate research tools, a small quantity of variables or incorrectly chosen parameters. Coleman (1975) used variables of physical resources and social environment but ignored such decisive variables as school processes (a social system and culture). The aforementioned makes it appropriate to study the sociopsychological safety of the educational environment from the standpoint of an ecological approach (Gibson, 1986). Implementation of this approach at the empirical level implies an interdisciplinary paradigm of research and appeals to a wide range of contextual factors of the educational environment.

\section{Purpose and objectives of the study}

Purpose of the study was to empirically identify the types of educational environments based on an assessment of the sociocultural risks of the educational environment.

\section{Literature review}

In our study, we relied on an environmental approach. In environmental psychology, the basic concepts for constructing theories are "environment", "space", and "behavior". Environmental psychology studies the links between human behavior and its material environment. It is the scientific study of the relationship between a person and the environment - the relationship between environmental variables and various characteristics of the human psyche. The level approach in the educational environment is consistent with the concept of "embeddedness" in the theory of the ecological approach of Gibson (1986). Gibson defines the concept of "opportunity" as a unit of analysis of the educational environment. According to Gibson, the possibility is a category that binds and defines, on the one hand, the person, and on the other hand, it is a characteristic of the environment (Gibson, 1986). Several theories are offered for the analysis of the educational environment in literature: Input-Output theory, Sociological theory. According to the Input-Output theory, school is a firm that converts inputs into outputs. Each input is assumed in a linear fashion to contribute something to output; inadequate output calls for more of some input variables (money, time, materials, teaching techniques), or a shift in the allocation of the resources. According to the second theory, school is a cultural system of social relationships among family, teachers, students, and peers (Brookover \& Erickson, 1975). The third ecological theory was put forward by Barker (1974). We will be guided by ecological theory. If we address the typology of educational environments, 
most of them are constructed on the assessment of psychological climate. Wynne (1981) postulated coherent and non-coherent types of climate on the basis of his detailed case study observations in hundreds of schools. Halpin and Croft (1963) distinguished between open and closed climates. Referring to the typologies of educational environments from the standpoint of psychological security, it is important to mention the Ecological-Personal Model of Yasvin, Anthropo- psychological model of Slobodchikov, Communicative and Orientation Model of Rubtsov. At the same time, the problem of an empirical analysis of the sociocultural risks of the educational environment remains an open field for discussion. At the same time, it is the contextual factors of the educational environment that often determine the specificity of influences from the wider context in which this environment is included (Bronfenbrenner, 1989) and the problems of the socio-psychological security of a particular educational environment. Based on this, the study focused on the following research questions: (1) what is the significance of contextual factors of socio-psychological security? (2) how exactly do the sociocultural risks of the educational environment influence the socio-psychological safety of the educational environment?

\section{Conceptual Framework}

Using the ontological deployment method, we designed an educational environment consisting of 4 core processes that explain its specificity: individualization, formation, modernization, and integration. The structures responsible for the effectiveness of the implementation of pivotal processes are called the process carriers. The model of the educational environment is named "Process-morphological model of the educational environment" (Gilemkhanova, 2018).

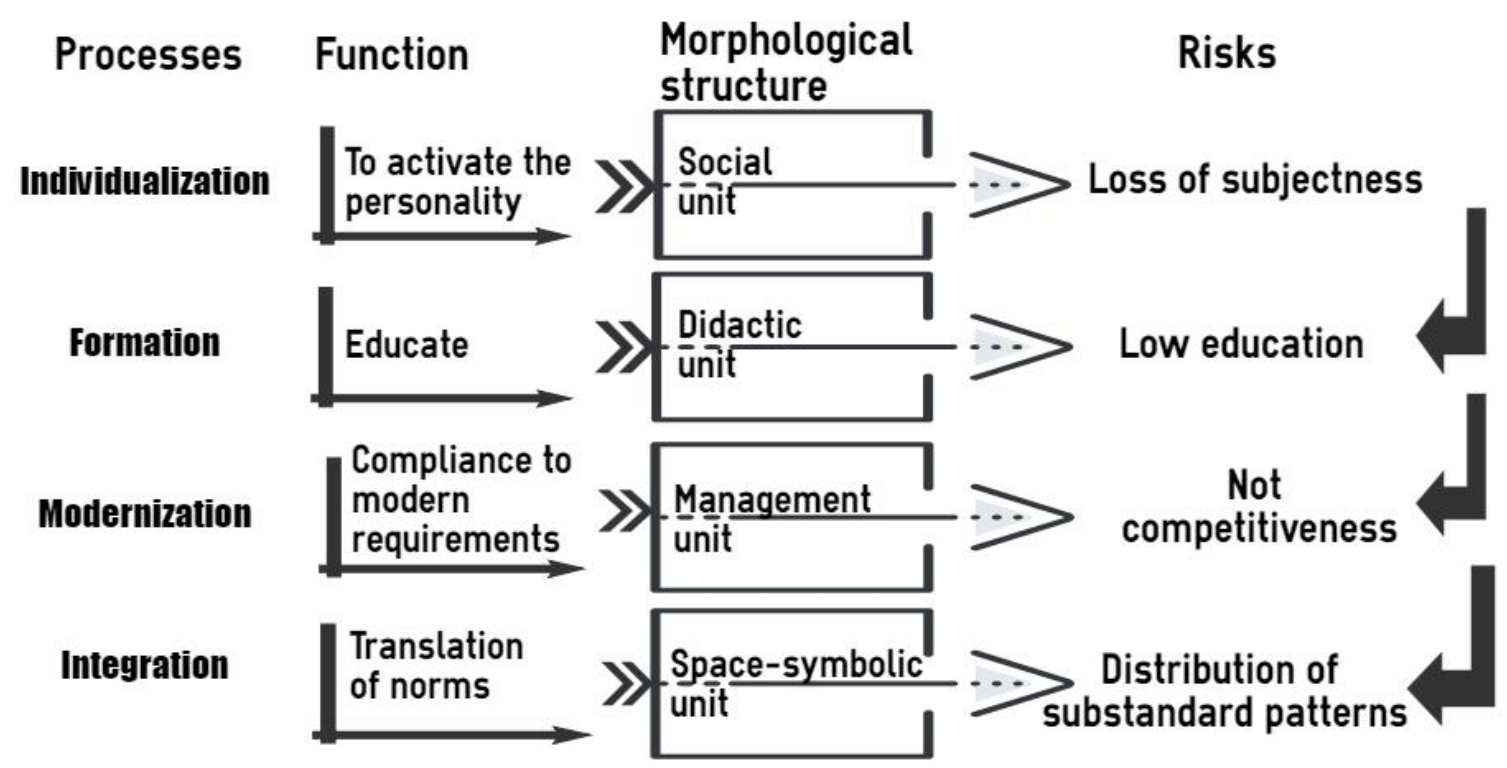

Figure 1. Process-morphological model of the educational environment

The goal of each process is to achieve the result determined by a morphological structure. The goal of individualization is to activate the personality. It is implemented by the social unit - the system of relationships and interactions of the subjects of the educational process within the educational environment. The organization of interaction at the level of dynamic equilibrium of goals and values of 
subjects of the educational process, as well as individuals and various groups and teams included in the educational system, is important within the core process of individualization. The underlying risk in the framework of this direction is the loss of personality and social apathy, anomie. Purpose of formation is in training and education of the individual which is achieved by means of a didactic unit. It is characterized by the effectiveness of training and education. The purpose of modernization is to meet all possible requirements. The management unit is responsible for the implementation of this goal. The purpose of the integration is the translation of norms of behavior. It is achieved through space-symbolic unit. It is primarily within the territorial location of the school. Topological consideration determines cultural norms and stereotypes, opportunities, and prospects. Despite the processes of globalization, the system of interactions and life dominate in determining the consciousness and behavior of the individual.

Our model lashes with the interactive model showing all possible relationships among environmental dimensions and their interactions with student outcomes presented in the work by Anderson (1982). An interactive model has 4 main components: milieu, ecology, social system, culture.

North (2005) writes about the need or a current trend to "transform uncertainty into risk". The more variables and social-psychological security will be determined and objectified as the risk, the greater the variability the education system will have in the system of risk data management. Key to this study is the concepts of the sociocultural risk of the educational environment, socio-psychological security of the educational environment. The sociocultural risk of the educational environment of a school is defined by the author as the degree of divergence of purpose and the result due to the inconsistency of the morphological structure to the procedural structure within the polystructural system of the educational environment. An important category for risk assessment is the concept of security. Psychological security is determined as the environment in which you can freely risk, experiment and cooperate (Newman, Donohue, \& Eva, 2017). Edmondson (1999) considers psychological security from the point of view of the psychological climate in a group and defines it as the general confidence of team members that the team is safe for interpersonal risk-taking. Newman, Donohue, \& Eva (2017) define psychological safety as the degree to which people feel safe and confident in their ability to manage change. Many psychological security studies are undertaken at one of the three levels: personal, team or organizational (Frazier, Fainshmidt, Klinger, Pezeshkan, \& Vracheva, 2017). However, there is still little psychological security presented in the study of the educational system. Socio-psychological safety of the educational environment is, from the point of view of the author, a backbone characteristic of the quality of the educational environment. The socio-psychological safety of the educational environment of a school is considered as the consistency of the components of the polystructural system of the educational environment, ensured by the consistency of morphological structure and procedural structure through a set of psychological, pedagogical, socio-economic, geographical, and ecological conditions of the educational process.

\section{Methodology}

As Anderson (1982) indicates, a particular problem with studies into school effects involves decisions about the level of data to be used. Inevitably, multilevel educational data are involved (Burstein, 1980), so the real debate is not about what level but what level is used for what variables. In article author's vision of the solution of this methodological question is realized by means of a dichotomizing approach in the research design. The design of the study suggested conducting research in identified areas based on the analysis of territories with optimal and worst indicators for each context parameter studied. Earlier the 
author conducted the research (Gilemkhanova, 2018) which showed a role of these contextual factors in ensuring socio-psychological safety of regional units. Thus this research relies on results of the previous research conducted at the level of municipal districts and shown that the used contextual parameters can be accepted as predictors of socio-psychological safety of the educational environment of school. Data of the previous research formed a basis for the choice of schools of this research. As a result, 36 schools were included in the study. Schools were localized in 9 different territorial-administrative units with a total enrollment of 3232 pupils at the age of 13-17 years. Statistical analysis of the data was carried out using cluster analysis, factor analysis, and the principal component method.

The distribution of data reported by participants is presented in Table 1.

Table 1. Frequencies for the demographic variables according to gender.

\begin{tabular}{|l|l|c|c|c|}
\hline \multicolumn{2}{|c|}{ Gender } & Frequen & Percent & \begin{tabular}{c} 
Valid \\
\multicolumn{2}{|c|}{}
\end{tabular} \\
Calid & Male & 1456 & 45 & 45 \\
\cline { 2 - 5 } & Female & 1618 & 50 & 50 \\
\cline { 2 - 5 } & Not specify & 158 & 5 & 5 \\
\cline { 2 - 5 } & Total & 3232 & 100 & 100 \\
\hline
\end{tabular}

The sample is formed of $50 \%$ females and $45 \%$ males.

The study applies the following sociocultural factors: training, education, psychological, social, economic, and geographical factors. The predictor variables included (a) average salary in rubles survey item, (b) the percentage of the employed people in the region survey item, (c) index of school's education rating, (d) index of upbringing rating of the school, (e) type of the settlement, (f) the availability percentage of school psychologists in the region, (g) psychological service (Table 2). Information about contextual factors was obtained on the republican portal of the Ministry of Education and Science of the Russian Federation and on the website of the Federal State Statistics Service. The outcome variable included pupil's sociocultural safety index. It was examined by our tool "Adolescence socio-cultural safety index" (Table 1).

Table 2. Descriptions of measures included in analyses.

\begin{tabular}{|l|l|}
\hline $\begin{array}{l}\text { Outcome variable } \\
\text { Index of safety }\end{array}$ & $\begin{array}{l}\text { Technique "Adolescence socio-cultural safety index" } \\
\text { (E. Gilemkhanova). 3375 pupils from } 13 \text { to } 16 \text { years }(53 \% \text { of girls, } 47 \% \text { of } \\
\text { boys) participated in a research. Psychometric characteristics of a } \\
\text { technique are provided: reliability }(\alpha \mathrm{Cr}=0.76) \text {, validity }(\mathrm{r}=0.71), \\
\text { discriminatory power }(\delta=0.9) . \\
\text { Technique "Adolescence socio-cultural safety index" has general scale "Index } \\
\text { of sociocultural safety" and } 3 \text { additional scales: } \\
1) \quad \text { socio-psychological vulnerability; } \\
2) \quad \text { socio-psychological disintegration; } \\
3) \quad \text { virtual autization. } \\
\text { Socio-psychological vulnerability- characteristic of the subject of school } \\
\text { interactions, causing high susceptibility to risks of the educational } \\
\text { environment. It is connected with passivity, pliability to external influence, } \\
\text { hypersensitivity to nuances of social interaction. Problems of social and }\end{array}$ \\
\hline
\end{tabular}




\begin{tabular}{|c|c|}
\hline & $\begin{array}{l}\text { psychological interaction of the pupil and other subjects of an educational } \\
\text { system are expressed in the self-destroying trends, the direction of destructive } \\
\text { impulses on themselves, and is followed by sense of guilt, the sensitivity } \\
\text { increased by uneasiness. } \\
\text { Examples of questions: } \\
\text { For some reason as a rule all cones pour on me. } \\
\text { If other people cause in me delight and a charm, I am disappointed in myself } \\
\text { more and more. } \\
\text { Socio-psychological disintegration - characteristic of the subject of school } \\
\text { interactions, who's problems connected with a mismatch of individual mental } \\
\text { introject and dispositions with background characteristics of the educational } \\
\text { environment and subjects of educational process. Key risk - isolation, the } \\
\text { estrangement defining also inertness and not inclusiveness in an educational } \\
\text { system. } \\
\text { Examples of questions: } \\
\text { I am not satisfied with those relations which at me developed with } \\
\text { schoolmates. } \\
\text { I would like to pass into other class. } \\
\text { Virtual autization characteristic of the subject of school interactions, causing } \\
\text { social and psychological disadaptation as a result of the broken social } \\
\text { interaction which is expressed in preference of the depersonalized } \\
\text { communication, problems of self-identification, marginal identity and an } \\
\text { unproductive reflection. } \\
\text { Examples of questions: } \\
\text { Communication is more free and entertaining on social networks. } \\
\text { The avatar or the status incognito on social networks allows me more stoutly } \\
\text { to prove myself, without being distracted by insignificant details. }\end{array}$ \\
\hline \multicolumn{2}{|l|}{ Contextual variables } \\
\hline Salary & $\begin{array}{l}\text { Average amount of salary in rubles: } \\
\text { High level }-16 \text { schools } \\
\text { Average level }-16 \text { schools } \\
\text { Low level }-4 \text { schools }\end{array}$ \\
\hline Employment & $\begin{array}{l}\text { Percentage of employed people in the region: } \\
\text { High level }-8 \text { schools } \\
\text { Average level }-12 \text { schools } \\
\text { Low level }-12 \text { schools }\end{array}$ \\
\hline $\begin{array}{l}\text { Index of school's education } \\
\text { rating }\end{array}$ & $\begin{array}{l}\text { The integral characteristic of the school's education rating includes the } \\
\text { following figures: the proportion of the winners of competitions, proportion of } \\
\text { students who have received the } 80 \text { points or more on State Unified Exam } \\
\text { (all subjects), the average score for Russian Language on State Unified Exam } \\
\text { and the average score on the subject of choice, proportion of students who did } \\
\text { not pass State Final Certification. }\end{array}$ \\
\hline
\end{tabular}




\begin{tabular}{|l|l|}
\hline & $\begin{array}{l}\text { High level }-8 \text { schools } \\
\text { Average level }-12 \text { schools } \\
\text { Low level }-16 \text { schools }\end{array}$ \\
\hline $\begin{array}{l}\text { Index of upbringing rating } \\
\text { of the school }\end{array}$ & $\begin{array}{l}\text { The integral characteristic of efficiency in the sphere of additional education } \\
\text { and upbringing is made up by the following indicators: resource provision of } \\
\text { education, development of additional education in educational } \\
\text { organizations, cultural and recreational sports and mass work, the } \\
\text { development of children's movement, national and artistic } \\
\text { activities, prevention of asocial behavior, suicides, addictions in children and } \\
\text { teenagers. } \\
\text { High level }-8 \text { schools } \\
\text { Average level }-16 \text { schools } \\
\text { Low level }-12\end{array}$ \\
\hline Type of the settlement & $\begin{array}{l}3 \text { types were identified: city, urban-type settlements, village. } \\
8 \text { settlements had the status of the city, 16 urban-type settlements, 12 villages. }\end{array}$ \\
\hline $\begin{array}{l}\text { Availability percentage of } \\
\text { school psychologists in the } \\
\text { region }\end{array}$ & $\begin{array}{l}\text { The indicator was calculated on the basis of correlating the number of school } \\
\text { psychologists in schools to the total number of students within each territorial } \\
\text { unit. } \\
\text { High level - 16 schools } \\
\text { Average level - } 8 \text { schools } \\
\text { Low level }-12 \text { schools }\end{array}$ \\
\hline
\end{tabular}

\section{Procedure}

Pupils filled out the printed-out questionnaires in the class. The psychologist of school was instructed by a technique and could explain research objectives and the planned results and to give instructions of rather correct end of the questionnaire. Pupils have to answer questions of the questionnaire, having chosen one of four possible answers: 1) yes; 2) rather yes then no; 3) no; 4) rather no, then yes. Each item was recoded such that "yes" has 4 score, "rather yes then no" has 3 score, "rather no, then yes" has 2 score, "no" has 1 score. Participants demanded that about 30 minutes that they finished the questionnaire.

\section{Results}

As a result of factorization of variables, 9 groups were identified. The identification of indicators with maximum factor load within each group allowed us to distinguish the features of each group and make configurations of educational environments according to the combination of contextual factors of varying severity: high, medium, low.

As a result of factorization of variables 7 groups were obtained by principal components analysis PCA).

Table 3.

Results of principal components analysis 


\begin{tabular}{|l|l|}
\hline Psychological service & The indicator was calculated on the basis of existence and efficiency of \\
& psychological service \\
& High level -16 schools \\
& Average level -8 schools \\
& Low level -12 schools
\end{tabular}



Com
C. 2
C. 3
C.
C.
C.
C.

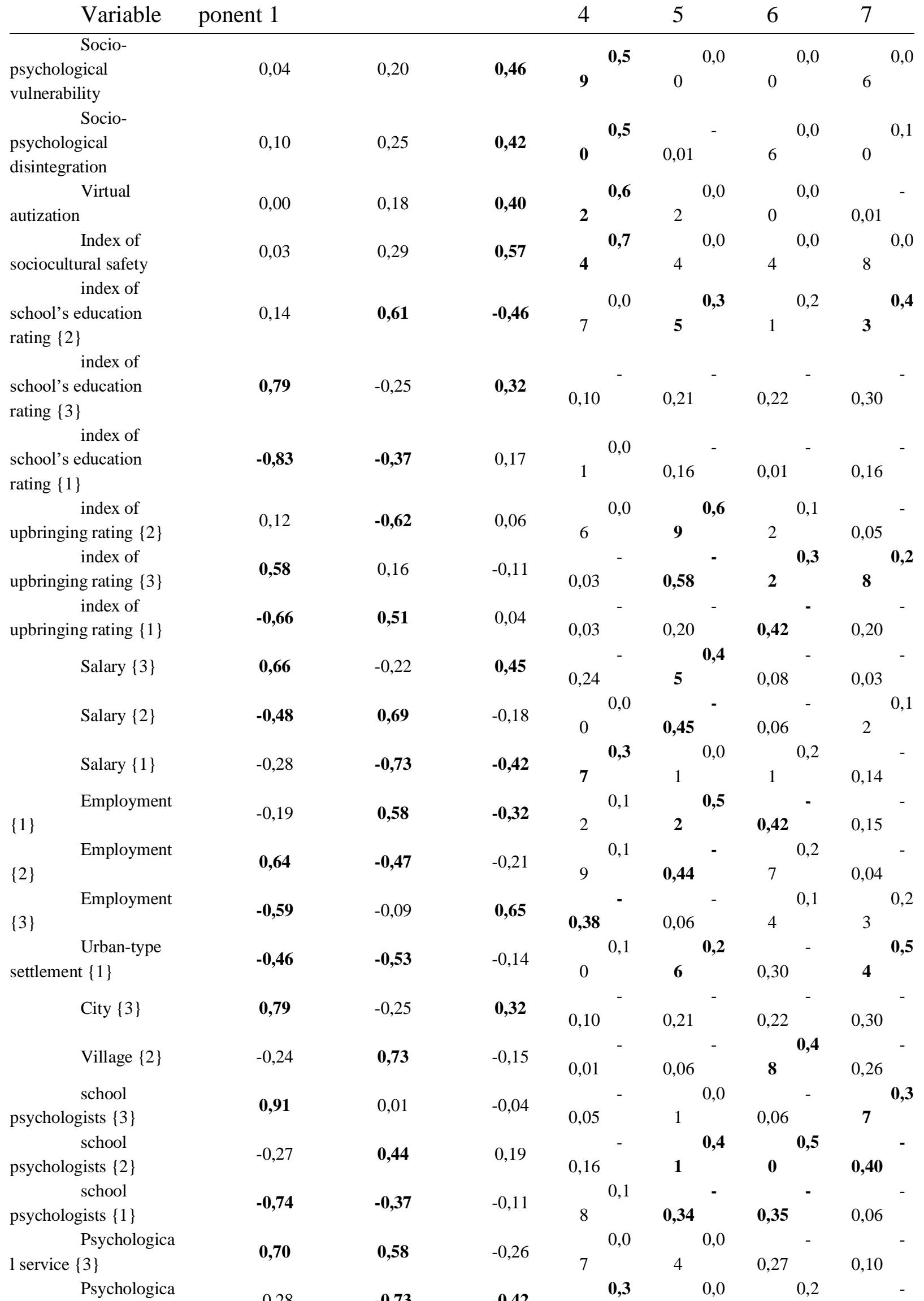




\section{Types of supportive educational environments}

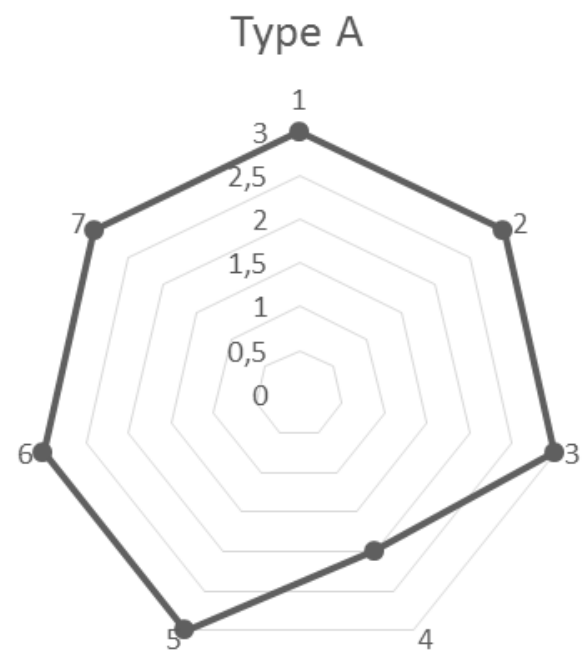

Figure 2. Configuration of educational environment parameters with favorable sociopsychological security type A.

Note: 1- level of education rating; 2- level of upbringing rating; 3- level of salary; 4- level of employment; 5- type of the settlement (3-grade-urban-type; 2-grade-settlements; 1-grade-villages); 6- level of security with school psychologists; 7- level of psychological service.

The type A educational environment profile can be described as a Perfection- favorable urban option. All parameters, psychological, educational, economic are in the zone of greatest severity. Turning to the procedural-morphological model in this type of educational environments, all core processes: individualization, formation, modernization, and integration ensure the formation of the sociopsychological safety of the educational environment of an urban type, paying attention to all aspects of the pedagogical process: education, upbringing and development. 


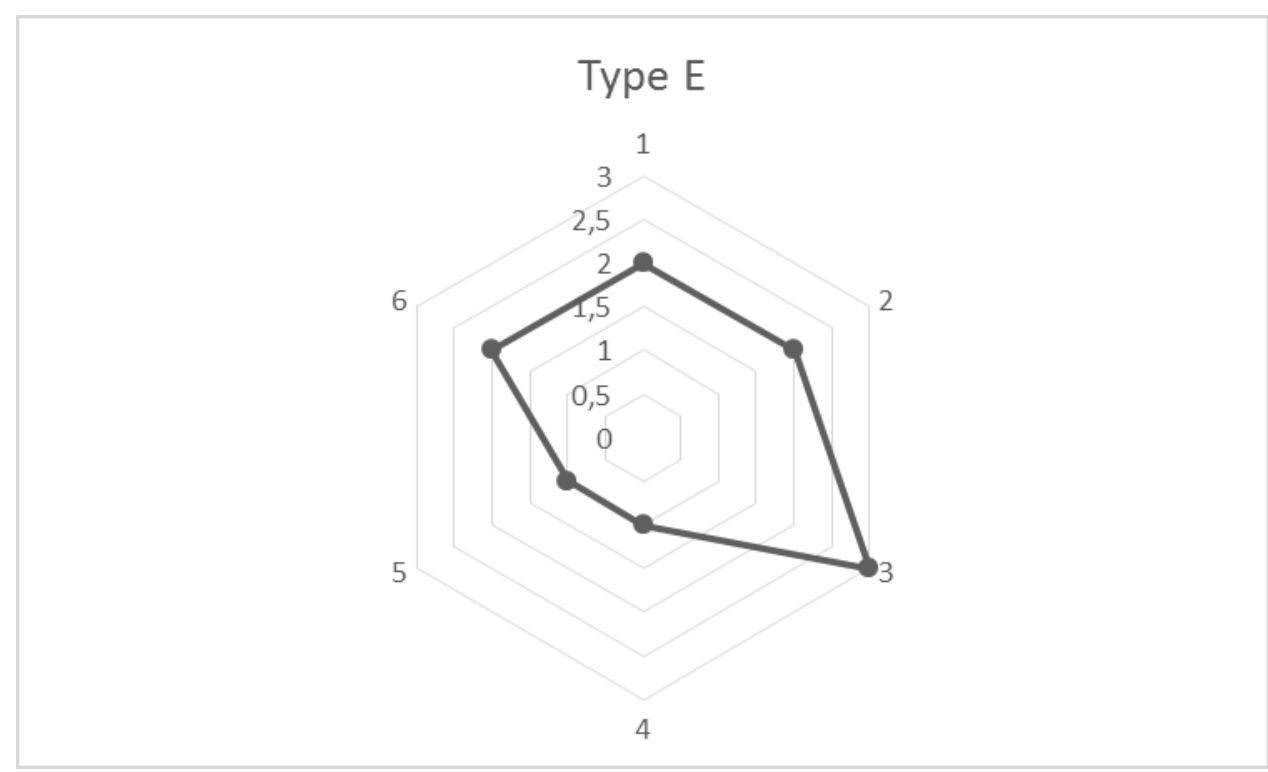

Figure 3. Configuration of educational environment parameters with favorable sociopsychological security type $E$.

The profile of educational environment type E can be described as a Favorably-comfortable (median) rural option. This educational environment does not form perfectionist claims, remaining in the middle zone for the quality of training and education. In this educational environment, there is psychological support of the educational process, but it is not a priority. At the same time, these are probably those rural settlements that are located on the territory of economically free zones, where the population is concentrated on implementing large projects subsidized by the state, but the proportion of this population does not cover everyone living in this territory. The key characteristic of this educational environment is comfort.

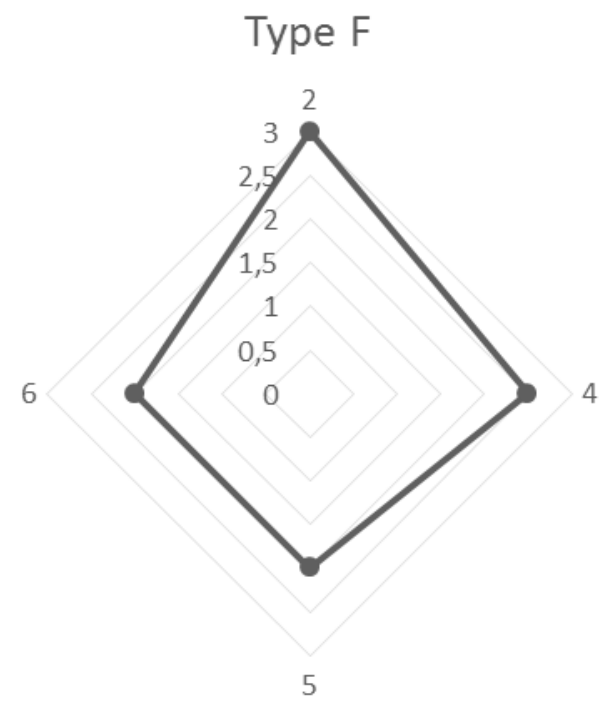

Figure 4. Configuration of the parameters of the educational environment with favorable socio- 
psychological security type $F$

The profile of the educational environment of type Fcan be described as an Incultural (fostering) township variant of the educational environment that is favorable from the point of view of the socio-psychological adaptation. It is characterized by the emphasis on upbringing and providing psychological support for students. In this type of educational environment enculturation (integration according to the model) dominates, that is, the transmission of norms of activity and thinking, which is carried out through orientation on upbringing.

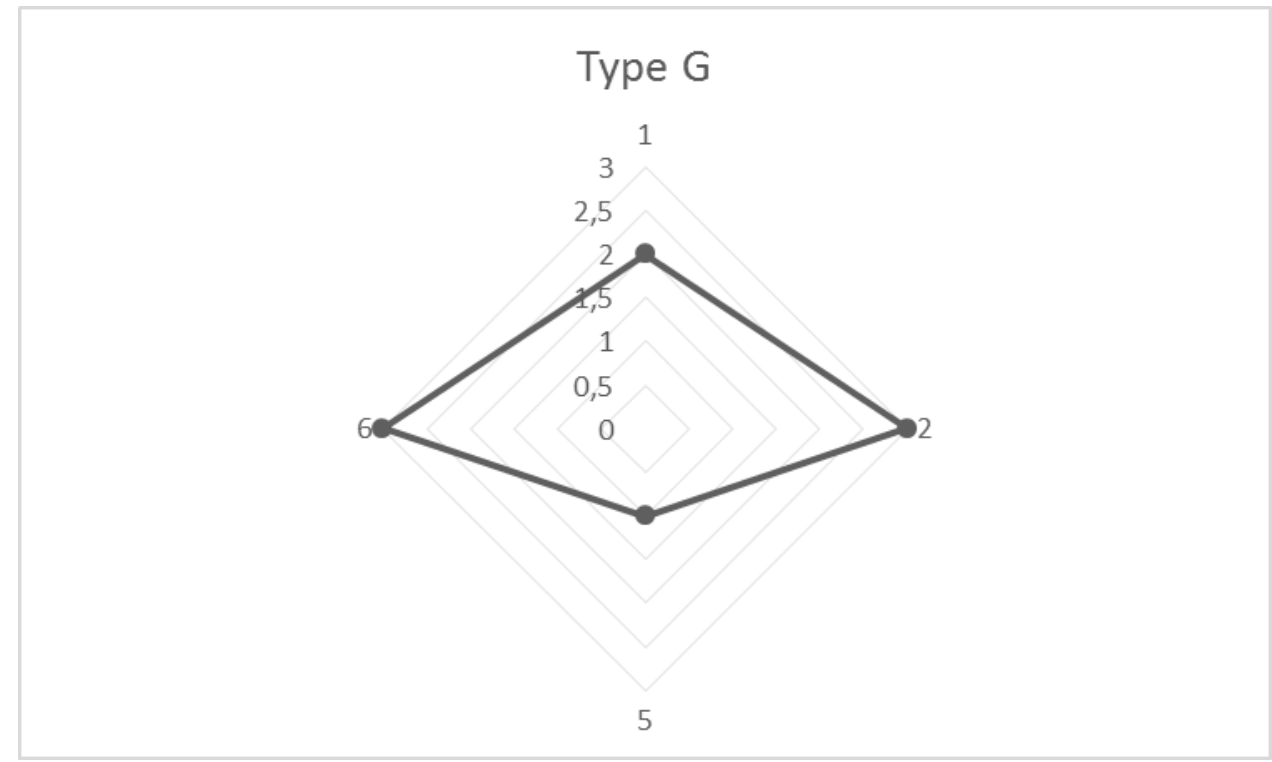

Figure 5. Configuration of the parameters of the educational environment with favorable sociopsychological security type $G$

The profile of the educational environment of type G can be characterized as an Inculturaldeveloping rural option favorable from the point of view of the socio-psychological adaptation of the educational environment. In this type of educational environment, the emphasis is placed on the upbringing and psychological support of students while maintaining a focus on learning. At the same time, priority is given to personal development. From the standpoint of the model, this configuration is characterized by the dominance of the processes of individualization and integration, that is, the translation of the norms of activity and thinking and the activation of the student's personality, that is, the development of their subjectivity.

Types of adverse educational environments 


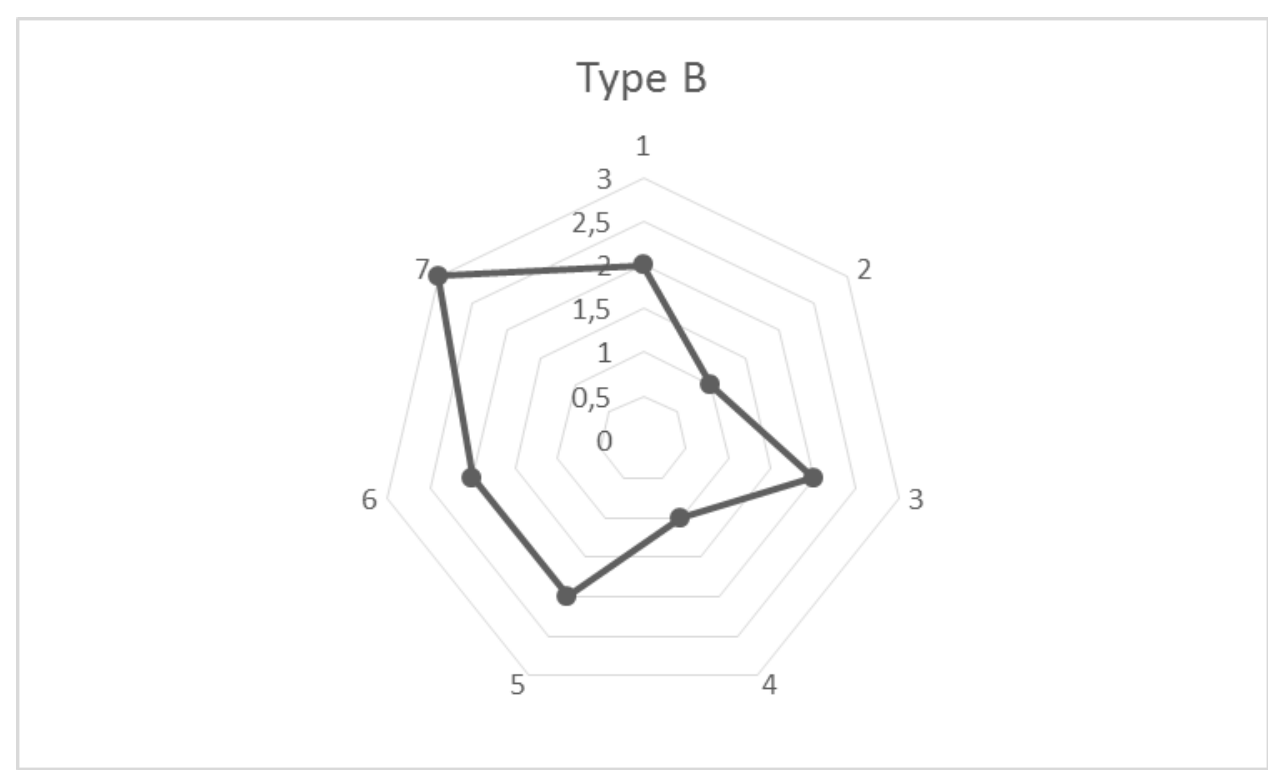

Figure 6. Configuration of the parameters of the educational environment with conditionally unfavorable socio-psychological security type $B$

The type B educational environment profile can be described as a Destructive-imitating village variant. A feature of this type is ignoring the educational unit in the presence of psychological support. Employment is low, wages are average. There are centers of psychological and pedagogical support on the territory and a sufficient number of psychologists, but the educational environment itself does not have clear targets, is amorphous, which is reflected in the formation of a socially apathetic personality of students and the dissemination of non-normative standards of behavior.

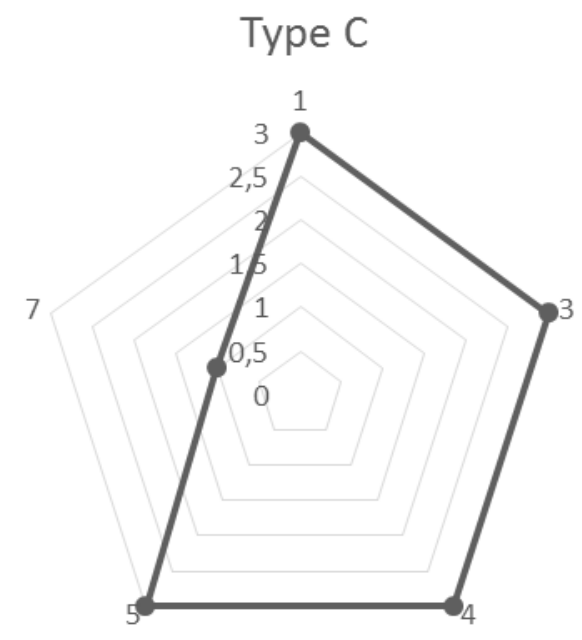

Figure 7. Configuration of educational environment parameters with unfavorable sociopsychological security type $C$

The type $\mathrm{C}$ educational environment profile can be described as a Destructive- 
perfection urban option. Having a clear focus on high educational achievements of students the psychological and educational components of the educational process are ignored in highly competitive sociocultural environments. Personality formation occurs in tough competitive conditions outside the processes of individualization and integration. It can be said that core processes polarize in this educational environment: formation and modernization are opposed to individualization and integration. With significant similarities between configurations $\mathrm{A}$ and $\mathrm{C}$, the key difference is the noninclusion in the educational environment of upbringing and psychological and pedagogical support, which causes an educational environment that is unfavorable from the point of view of socio-psychological security.

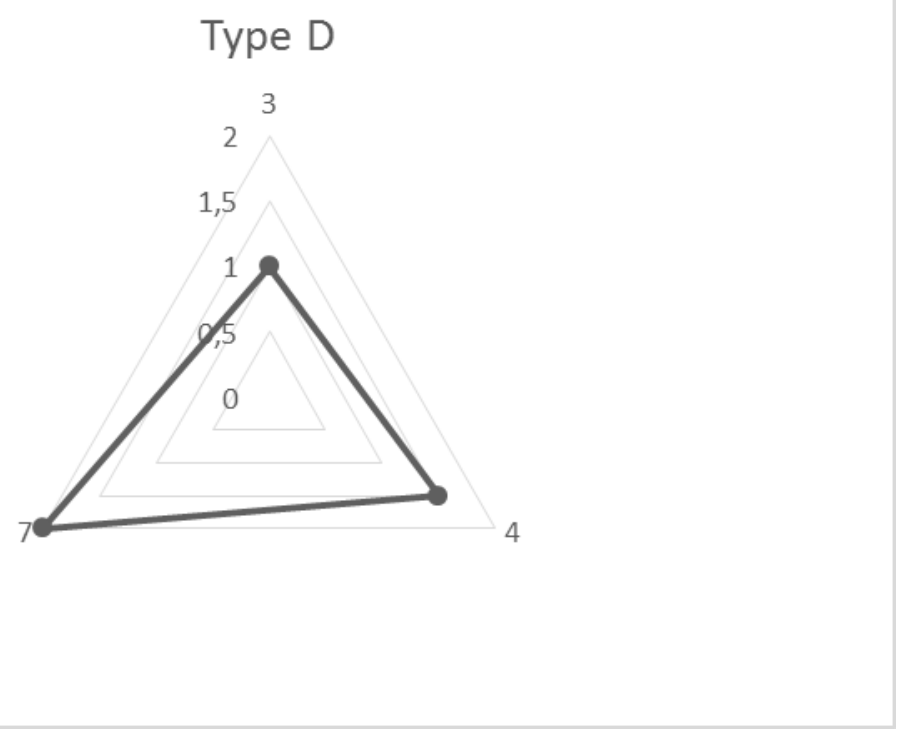

Figure 8. Configuration of the parameters of the educational environment with extremely unfavorable socio-psychological security type $D$

The profile of the educational environment of type $\mathrm{D}$ can be defined as a Lowstructured noncompetitive educational environment. In the presence of psychological and pedagogical services and centers, this environment is characterized by socioeconomic non-competitiveness, which causes extremely unfavorable social and psychological security of students. This type of educational environment must be taken under close attention. According to the model, all core processes do not implement the functions assigned to them under given conditions.

\section{Discussions}

A number of researchers including Saarento, Garandeau, and Salmivalli (2015), Hall and Chapman (2018) believe that there are no fundamental differences in the riskiness of the educational space, fixing the social level of this problem. They underline that they do not find differences in the prevalence of this phenomenon specified by the type of school environment or socioeconomic contextual factors. This problem is identified by these authors as a supra-context problem. This explains the low percentage of dispersion, depending on contextual factors. Along with this, Hong and Espelage (2012) emphasize that an effective preventive strategy should focus on an environmental approach. Support of this approach makes it necessary to consider the possibility of taking into account certain variables that affect the context in 
which they are applied. Wang et al. (2019) found that the type of population affects the victimization in the educational environment. Kisfalusi (2018) also showed that the academic performance and socio-economic status of students have a significant impact on the level of social and psychological vulnerability of students.

A comparative analysis of the configurations of educational environments according to the types of settlements allowed us to allocate contextual resources for the development of unfavorable educational environments.

Table 4. Analysis of the types of socio-psychological security based on the effectiveness of the implementation of the core processes of the educational environment

\begin{tabular}{|c|c|c|c|}
\hline & $\begin{array}{l}\text { Types } \\
\text { of adverse } \\
\text { educational } \\
\text { environments }\end{array}$ & $\begin{array}{l}\text { Typ } \\
\text { es of } \\
\text { supportive } \\
\text { educational } \\
\text { environments }\end{array}$ & Recommendation \\
\hline $\mathrm{C}$ & Type & e A & 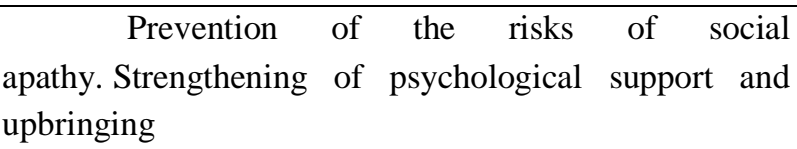 \\
\hline $\begin{array}{r}S \\
\text { ettlement }\end{array}$ & Type & Тур & $\begin{array}{l}\text { Prevention of the risks of irregular standards } \\
\text { spreading, assistance in the socio-economic } \\
\text { development of the region }\end{array}$ \\
\hline illages & Type & Тур & $\begin{array}{l}\text { Moderate attention to all core processes of the } \\
\text { educational environment }\end{array}$ \\
\hline $\begin{array}{ll} & \mathrm{G} \\
\text { eneral } & \end{array}$ & Type & Тур & $\begin{array}{l}\text { For all territories: increasing attention to the } \\
\text { transmission of normative standards, socio-economic } \\
\text { support }\end{array}$ \\
\hline
\end{tabular}

It is important to mention, that the characteristic feature for all types of favorable environments is that a large value is given to an integration process. Integration, on the one hand, consists in translating the norms of activity and thinking, on the other hand, it is associated with education as a form of interiorization of norms. On the contrary, this indicator is either absent in the configuration in unfavorable types, or a low level of implementation of upbringing as a pivotal process is shown. The effect of integration processes in school on students' victimization was indicated by Vitoroulis, Brittain, and Vaillancourt (2016).

The same level of learning in the educational environments shows that high learning outcomes are typical of both favorable and unfavorable environments. Also, modernization does not affect the level of socio-psychological security of the educational environment. Both types of environments are also found in different types of settlements but have different configurations for other contextual factors. The provision of psychological support for the educational process also does not have critical value for sociopsychological security and has a cumulative effect only in interaction with other contextual factors.

Depending on the geographical location, the nature of measures to improve the sociopsychological security of educational environments will vary. In areas with an unfavorable combination of 
educational environment parameters, it is advisable to use resources that do not participate in the configuration of parameter, or to enhance the role of those parameters that can be influenced within the educational system.

In disharmonious educational environments, the emphasis on upbringing prevents the risks of the unfavorable educational environment. The role of upbringing and psychological support is argued from the standpoint of analyzing contextual factors of the educational environment. Socio-economic conditions can be adjusted by the psychological and pedagogical conditions of the educational environment. Rural and township educational environments have great potential since they are focused on the implementation of integration processes. Rural and township safe educational environments are distinguished by an emphasis on inculturation (upbringing) and psychological support. Safe educational environments are characterized by an orientation towards individualization and inculturation (integration).

\section{Conclusion}

Based on a large-scale empirical study, 7 types of educational environments for sociopsychological security were identified: 4 favorable and 3 unfavorable. All favorable environments are distinguished by attention to the processes of inculturation, that is, transmission of norms and standards of an activity, thinking and behavior through upbringing, as well as psychological and pedagogical accompaniment, paying attention to the processes of activating the student's personality, the development of his subjectivity. It is an active position of a person that determines the socio-psychological security as the degree of contact (interaction) of a person and a contextual level of the educational environment in the framework of the "person of the educational process - sociocultural environment of the educational organization". It ensures the implementation of the educational goals by the subject of the educational process, taking into account the complex psychological, pedagogical, socio-economic, geographical, environmental conditions of the educational process.

Allocation of these types of educational environments according to the degree of their sociopsychological security is important from the point of view of the timely implementation of preventive measures in order to avoid various destructive manifestations of socialization, such as addictive, delinquent behavior and other types of troubled behavior. The type of configuration of the educational environment can determine adequate measures to improve the social and psychological security of the educational environment, taking into account the optimal concentration of its contextual resources and socio-cultural risks.

\section{Acknowledgment}

The work is performed with the financial support for the project 17-29-02092 by the RFBR.

\section{References}

Argyris, C. (1958). Some problems in conceptualizing organizational climate: a case study of a bank. Administrative Science Quarterly, 2, 501-520.

Barker, R. G. (1974). The ecological environment. Issues in Social Ecology, 255-266.

Bronfenbrenner, U. (1989). Ecological systems theory: annals of child development. Cambridge, MA: Harvard University Press.

Brookover, W. B., \& Erickson, E. L. (1975). Sociology of education. Homewood: Dorsey Press.

Burstein, L. (1980). Chapter 4: the analysis of multilevel data in educational research and 
evaluation. Review of Research in Education, 8(1), 158-233.

Coleman, J. S. (1975). Methods and results in the IE A studies of effects of schools on learning. Review of Educational Research, 45, 355-386.

Edmondson, A. (1999). Psychological Safety and Learning Behavior in Work Teams. Administrative Science Quarterly, 44(2), 350-383.

Frazier, M. L., Fainshmidt, S., Klinger, R. L., Pezeshkan, A., \& Vracheva, V. (2017). Psychological safety: A meta-analytic review and extension. Personnel Psychology, 70(1), 113-165.

Gibson, J. (1986). Environmental approach to visual perception. London: Psychology Press.

Gilemkhanova, E. N. (2018). Contextual factors in assessing the sociocultural risks of the educational environment. Paper presented at the XIX April International Scientific Conference on Economic and Social Development, High School of Economics, Moscow. https://conf.hse.ru/pubs/share/direct/220103399.

Hall, W. J., \& Chapman, M. V. (2018). The role of school context in implementing a statewide antibullying policy and protecting students. Educational Policy, 32(4), 507-539.

Halpin, A. W., \& Croft, D. B. (1963). The organizational climate of schools. Chicago: University of Chicago.

Hong, J. S., \& Espelage, D. L. (2012). A review of research on bullying and peer victimization in school: An ecological system analysis. Aggression and Violent Behaviour, 17(4), 311-322.

Kisfalusi, D. (2018). Bullies and Victims in Primary Schools: The Associations between Bullying, Victimization, and Students' Ethnicity and Academic Achievement. East European Journal of Society and Politics, 4(1), 133-158.

McPartland, J. M., \& Epstein, J. L. (1975). The interaction of family and school factors in open-school effects on students. Paper presented at the annual meeting of the American Educational Research Association, Washington, D.C. https://files.eric.ed.gov/fulltext/ED102703.pdf

Newman, A., Donohue, R., \& Eva, N. (2017). Psychological safety: A systematic review of the literature. Human Resource Management Review, 27(3), 521-535.

North, D. C. (2005). Understanding the process of economic change. Acta Oeconomica, 56(1), 117-126.

Peng-Wei Wang, Ray C. Hsiao, Li Ming Chen, Yu-Hsien Sung, Huei-Fan Ни и Cheng-Fang Yen Associations between callous-unemotional traits and various types of involvement in school bullying among adolescents in Taiwan //Journal of the Formosan Medical Association, 2019-0101, T 118 (1), P.50-56.

Reijntjes, A., Kamphuis, J. H., Prinzie, P., \& Telch, M. J. (2010). Peer victimization and internalizing symptoms in children: A meta-analysis of longitudinal studies. Child Abuse and Neglect, 34(4), 244e252. http://dx.doi.org/10.1016/j.chiabu.2009.07.009.

Saarento, S., Garandeau, C. F., \& Salmivalli, C. (2015). Classroom-and school-level contributions to bullying and victimization: A review. Journal of Community \& Applied Social Psychology, 25(3), 204-218.

Vitoroulis, I., Brittain, H., \& Vaillancourt, T. (2016). School ethnic composition and bullying in Canadian schools. International Journal of Behavioral Development, 40(5), 431-441.

Wang, P. W., Hsiao, R. C., Chen, L. M., Sung, Y. H., Hu, H. F., \& Yen, C. F. (2019). Associations between callous-unemotional traits and various types of involvement in school bullying among adolescents in Taiwan. Journal of the Formosan Medical Association, 118(1), 50-56.

Wynne, E. A. (1981). Looking at good schools. The Phi Delta Kappan, 62(5), 377-381. 